\title{
IMPACT OF PROPYL THIOURACIL ON TESTES FUNCTIONS AND SEMEN CHARACTERISTICS OF NEW ZEALAND WHITE RABBITS
}

\author{
E. E.Tharwat, M.M. Sabra, A. F. Hussein and Hanaa, H. Mansour
}

Department of Animal Production, Faculty of Agriculture, Ain Shams University, Po.68 Hadaiq Shubra, Cairo, Egypt, Corresponding author: etharwat2001@yahoo.com

\section{SUMMARY}

This study was carried out at Intensive Rabbit Production Unit, belonging to Agriculture Studies and Consultation Center, Faculty of Agriculture, Ain Shams University. The study was designed to investigate the effect of 6-n-propyl-2-thiouracil (PTU) injection on testicular development and semen characteristics of male rabbits under intensive production. Sixty three New Zealand White (NZW) male rabbits were used. Three male rabbits (zero time) were slaughtered, the rest was divided randomly into two groups, the first group (PTU) 30 animals were subcutaneously injected daily with PTU $20 \mu \mathrm{g} / \mathrm{g}$ live body weight from the $1^{\text {st }}$ day until the weaning (28 day of age) and the second group $(C)$ of 30 animals served as control and injected daily with the. The study showed that the treatment with PTU reduced $(P \leq 0.001)$ live body weight during pre and post weaning periods. Testis measurements increased $(P \leq 0.0001)$ in PTU treated group compared with control group at 30, 60, 90, 120 and 150 days of age. Seminiferous tubules and Leydig cells indices increased $(P \leq 0.001)$ in PTU treated group (71.42\% and $18.97 \%)$ compared with control group, respectively. The ejaculate volume of PTU treated rabbits was larger $(P \leq 0.001)$ compared with control rabbits. The average sperm concentration $/ \mathrm{ml}$ and advanced motility were $485.57 \times 10^{6}$ vs. $312.07 \times 10^{6}$ and $87.21 \%$ vs. $78.23 \%$ for PTU and control groups, respectively. The percentages of abnormal and dead spermatozoa were $16.07 \%$ vs. $20.95 \%$ and $5.03 \%$ vs. $12.33 \%$ for treated and control groups, respectively. In conclusion, the 6-n-propyl-2-thiouracil can be used to increase testis size, ejaculate volume and sperm concentration. Despite these promising results, the use of PTU to produce male rabbits with larger testes and a better quality of semen needs further investigations in order to reduce the number of males breeding for artificial insemination purposes.

\section{Keywords: Rabbit, propyl thiouracil, semen, thyroid hormones}

\section{INTRODUCTION}

Propylthiouracil is a thioamide drug used clinically to inhibit thyroid hormone production. In vivo and in vitro observations suggested that thyroid hormones play an important role in testicular development. Van Haaster et al. (1992) showed in rats that transient hypothyroidism induced by the reversible goitrogen 6-n-propyl- 2-thiouracil (PTU) treatment can result in great increases in testis size and sperm production when the timing of hypothyroidism corresponds to the period of Sertoli cell proliferation. To be effective, PTU treatment must commence during neonatal period Cooke et al., (1992) and Kirby et al. (1995). Kirby et al. (1996) found increased daily sperm production per gram of testis by $36 \%$ compared to control in commercial broilers fed with $0.1 \%$ dietary PTU from 6 to 12 weeks of age.

The objective of the present study was to investigate the effect of PTU on testis function and semen characteristics of the New Zealand White rabbits.

\section{MATERIALS AND METHODS}

\section{Animals and Treatments}

This study was carried out at the Intensive Rabbit Production Unit, belonging to the Agriculture Studies and Consultation Center, Faculty of Agriculture, Ain Shams University, Cairo, Egypt, on 63 neonatal New Zealand White male rabbits (NZW), three male kids were sacrificed just after birth (zero time). The rest of the kids were divided randomly into two groups, the first group (PTU), 30 animals were subcutaneously injected daily with PTU (Sigma-Aldrich) $20 \mu \mathrm{g} / \mathrm{g}$ live body weight from the $1^{\text {st }}$ day until weaning ( 28 days of age); the second group (C) of 30 animals served as control after being injected subcutaneously daily with the vehicle. After weaning, experimental animals were reared in fattening rabbiteries under similar managerial and environmental conditions (natural day light). Commercial rabbit pelleted ration and drinking tap water were offered ad libitum until 90 days of age. After that the bucks were transferred to breeding cages where they were offered commercial rabbit pelleted ration and drinking tap water ad libitum and trained for artificial collection of semen.

\section{Measurements and Observations}

\section{Body Weight}

Body weights were recorded for each kid separately at birth, on a daily basis during preweaning; then at $45,60,75,90,105,120,135$ and 150 day of age.

\section{Anatomical Study}

Three kids were slaughtered at birth. At 15, 30, $45,60,75,90,105,120,135$ and 150 days of age three rabbits from each experimental groups (PTU treated and control rabbit) were slaughtered and the genitalia were removed. The testes were weighed using a sensitive electric balance (model Precisa 
205A SuperBal-series, Swiss Quality).Testis measurements including length, width and thickness were taken using a steel caliper.

\section{Blood Samples}

At $0,15,30,45,60,75,90,105,120,135$ and 150 days of age, a $2.0 \mathrm{ml}$ blood sample was taken during slaughtering. Plasma was collected and stored at $-20{ }^{\circ} \mathrm{C}$ for determination of $\mathrm{T}_{3}, \mathrm{~T}_{4}$ (Monobind Inc. Lake Forest, CA. 92630, USA) and testosterone levels by hormonal enzymatic methods using available commercial kits for testosterone (Calbiotech Inc., 10461 Austin Dr, Spring Valley, CA, 91978).

\section{Histological Measurements:}

After the anatomical studies of male rabbit genital organs at ages 30,60, 90, 120 and 150 days a specimen of the testis was fixed directly in Bouin's fixative for 24 hours and then transferred directly to $70 \%$ (v/v) ethyl alcohol. Testis samples were dehydrated, cleared and embedded in paraffin wax (conventional method). Serial sections $(4 \mu$ in thickness) were cut by the rotary microtome (Erma optical works, Tokyo 422, Japan). Mounting and fixation were made by following routine methods. Sections were stained with Haematoxylin and Eosin accordingly to Campbell staining protocol (1956).

Epithelial thickness and both diameters of the seminiferous tubules and Leydig cell nuclei (length and width) were measured by using optical micrometers. Leydig cells were identified in the interstitial tissue by their oval-to-round nuclei in combination with the specific blue-purple staining of their cytoplasm. At least 24 seminiferous tubules and Leydig cell nuclei per testis were measured.

\section{Analysis of Semen Quality:}

Nineteen bucks (10 PTU treated and 9 control) were trained for artificial collection of semen using artificial vagina and a doe as stimulus animal as reported by Heidbrink et al. (1980). Two successive ejaculates within 15 minutes were collected from each buck weekly.

All devices of artificial collection of semen were thoroughly washed and sterilized before use. All glass devices were dipped in bath of ethanol $(70 \% \mathrm{v} / \mathrm{v})$ and ether (1:1) and dried before use. A total of 912 semen samples were collected between 105 and 344 days of age. The evaluation of parameters of semen quality included ejaculate volume, percentage of dead spermatozoa according to Campbell (1956), percentage of abnormal spermatozoa accordingly to Dott and Foster (1972), advanced motility and initial fructose accordingly to Mann (1948) and its modification by Mann (1964).

\section{Statistical Analysis}

The data were statistically analyzed using SAS (2000). Duncan's Multiple Range test (Duncan, 1955) was used for the comparison between the experimental groups. A repeated measurement model was used for body weight, histological measurements of the testis and semen quality parameters.

\section{RESULTS AND DISCUSSION}

\section{Body Weight:}

Body weight of PTU treated rabbits was lower than in controls during the last week of the suckling (between 21 and 28 days of age) Figure (1). After weaning, from 28 to 150 days of age, the body weight of PTU treated rabbits was significantly lower than in controls $(\mathrm{P} \leq 0.001)$ during the whole experimental period (Figure 2). Similar results were found by Nancy St-Pierre et al., (2003) who observed that body weights of the treated rats were lower than those of the control rats during PTU administration. Once the treatment was stopped, the growth rate of PTU treated pups increased, but the body weights of treated adult rats stayed still significantly lighter than those of the controls. Ariyaratane et al. (2000) also reported that hypothyroidism induced by ethane dimethane sulfonate treatment in rats provoked lower body weight than in control rats on day 7 of the treatment and thereafter. Simorangkir et al. (1995) showed that transient neonatal hypothyroidism in rats induced by PTU had significantly $(\mathrm{P} \leq 0.05)$ lower body masses than controls during PTU administration and failed to reach control values even at 135 days of age, when their body masses were still approximately 20\% lower than control values. Cooke et al. (1993) found that PTU decreased growth and body weight of all PTU treated rat pups, which remained significantly lighter than control at all ages up to 90 days. In our study, the reduction of body weight in PTU treated rabbits may be due to the inhibition of $\mathrm{T}_{3}$ and $\mathrm{T}_{4}$ secretion by the thyroid gland (Figures 3 and 4); our results agree with those of Tamasy et al., (1986), Kirby et al. (1992) and Simorangkir et al. (1995) in neonatal hypothyroid rats. Furthermore, Subudhi, et al. (2009) observed reduced basal metabolic rate in hypothyroid rats.

\section{Effect of PTU on plasma $T_{3}, T_{4}$ and Testosterone concentrations: \\ Thyroid Hormones:}

The results indicated that PTU treatment reduced $\mathrm{T}_{3}$ (Figure 3) and $\mathrm{T}_{4}$ (figure 4) plasma levels. After the PTU administration period (27 day of age), both hormones returned to their normal values at 120 days of age. Similar to these results, Tamasy et al, (1986) and Kirby et al. (1992) observed in rat pups with PTU induced neonatal hypothyroidism a substantial decrease in thyroxin $\left(\mathrm{T}_{4}\right)$ plasma concentrations and a moderate decrease in triiodothyronin $\left(\mathrm{T}_{3}\right)$ concentrations. Similarly, Simorangkir, et al., (1995) observed that transient neonatal hypothyroidism in rats induced by PTU, significantly decrease serum thyroxin $(\mathrm{P} \leq 0.05)$ at 10,20 and 30 days of age in comparison with control rats. At 120 days of age, thyroxin concentrations in all groups were similar.

\section{Testosterone}

Plasma testosterone of PTU treated male rabbits was significantly $(\mathrm{P} \leq 0.0001)$ higher than that of 


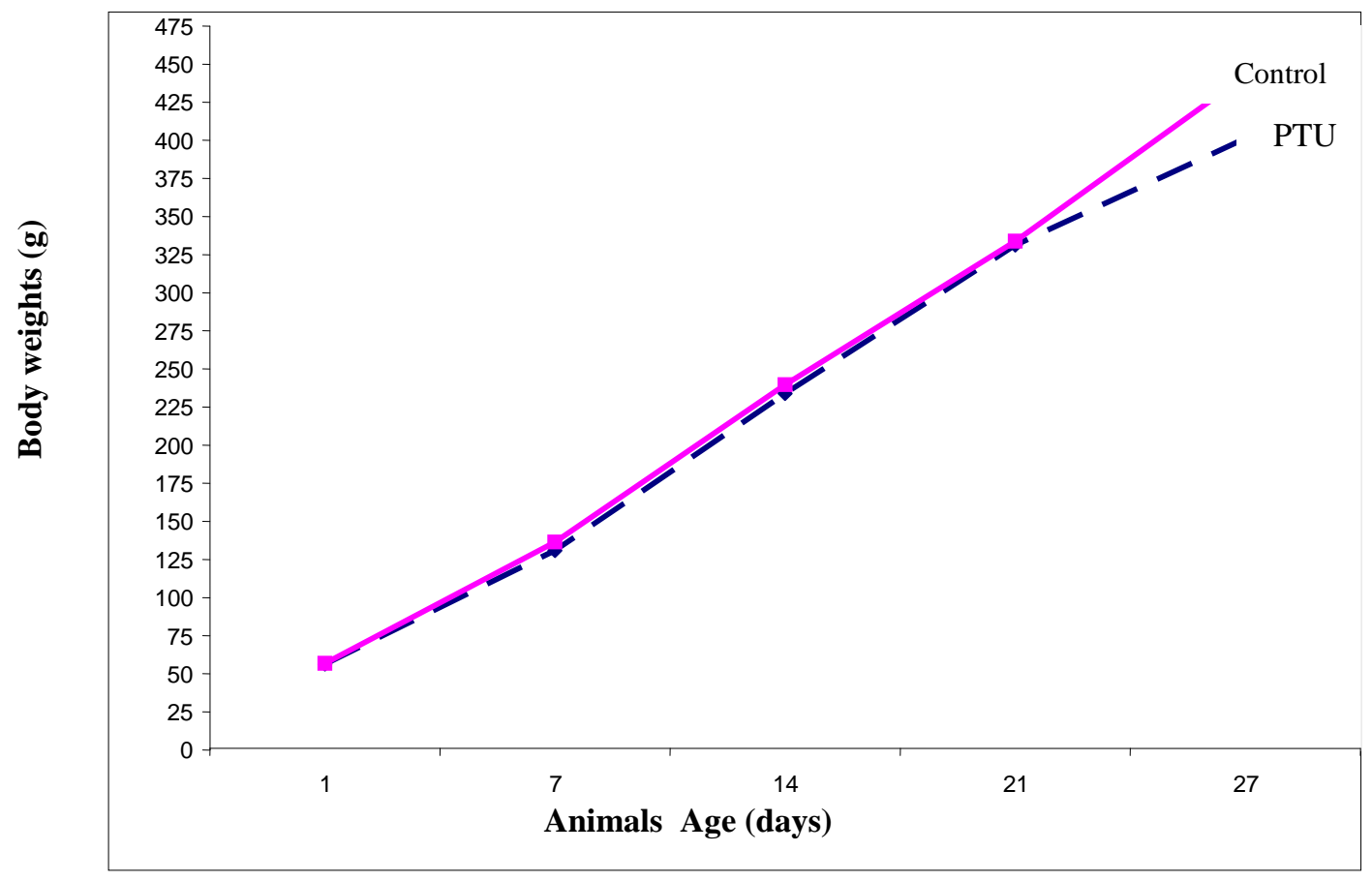

Fig. 1. Effect of PTU injection on pre-weaning body weight of male rabbits

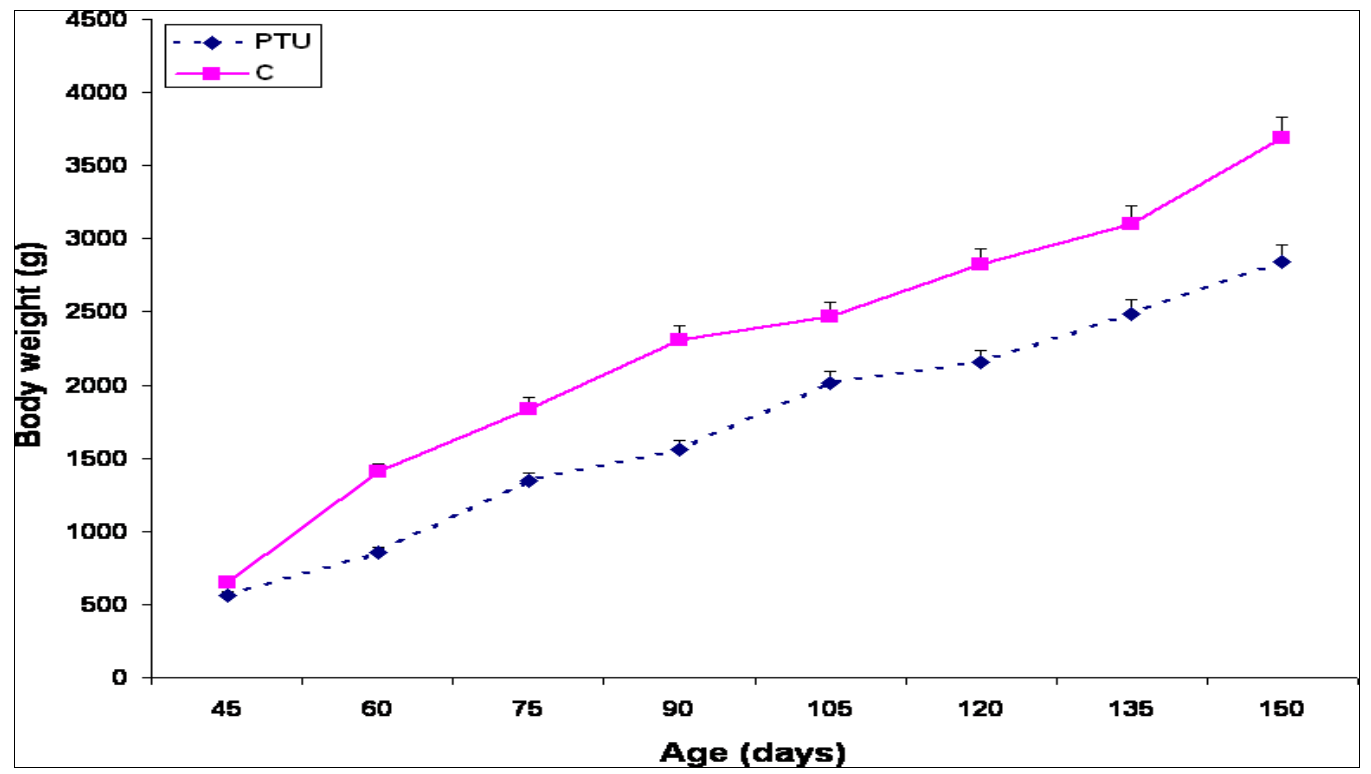

Fig. 2. Effect of PTU injection on post-weaning body weight of male rabbits

control group at 90 days of age (Figure 5). The relationship between hypothyroidism and testosterone concentration has not been studied before. In the opinion of the authors, the higher testosterone pulse frequency associated with advancing puberty in the PTU treated rabbits was more likely due to increased pulsatility of GnRH and LH, as demonstrated by Sanford et al., 1978, than to the changes in the FSH concentrations. These findings of the present study are comparable with the results of Knowlton et al., (1999) who reported that the sexual development in male turkeys improved when fed a diet with $0.1 \%$ PTU at 8 to 16 weeks of age. Plasma testosterone level of PTU treated birds was significantly higher than that of controls at 24 weeks of age. Also, in commercial broilers Kirby et al., (1996) found that feeding ration with $0.1 \%$ PTU after four weeks of photostimulation, produce significantly higher serum testosterone levels in the treated birds in comparison with the controls. In the current study, the increase of plasma testosterone concentrations in PTU treated rabbits may be due to an increase in Leydig cell size (Table 2) and/or number as proposed by others (Van Haaster et al., 
1992, Hess et al., 1993, Joyce et al., 1993, Hardy et al., 1993 and 1996 and Meisami et al., 1994).

\section{Anatomy of Testis:}

Compared with the control group the neonatal PTU injection significantly increased testicular length $(\mathrm{P} \leq 0.0001)$, width and weight in male rabbits (Table 2). Moreover, at 90 days of age, testis of PTU treated rabbit weighed $39.1 \%$ more than those of control. The percentage of testis with respect to live body weight was increased by $101.8 \%$ in the treated animals. Testicular length and width in treated rabbits enlarged by $14.16 \%$ and $4.34 \%$, respectively compared with controls (Table 1). These findings are comparable with the results of other studies in rats (Cooke and Meisami 1991, Cooke et al., 1994, Kirby et al., 1997 and Nancy St-Pierre et al., 2003), where neonatal PTU treatment from 0 to 28 days of age resulted in a $54.76 \%$ increase in the overall relative testis weight as compared with control. In the current study, the increase in testicular size of PTU treated rabbits may be due to hypertrophy and or hyperplasia of Sertoli cells and/or hyperplasia of the germ and Leydig cells (Tables 1 and 2). Van Haaster et al., (1992), Hess et al., (1993), Joyce et al., (1993), Hardy et al, (1993), Meisami et al., (1994), Hardy et al. (1993 and 1996) and Kirby et al. (1997) showed that transient neonatal hypothyroidism induced by treatment with PTU, increased testicular size in adult rat and mouse. In addition, at 90 days of age, testes of PTU treated rats weighed $62 \%$ more than those of control. The gross testicular length, width and size were enlarged by $13.7 \%$ and $7.6 \%$, respectively. In our study, the increase of testis weight in PTU treated rabbits may be due to hypertrophy and / or hyperplasia of Leydig cells.

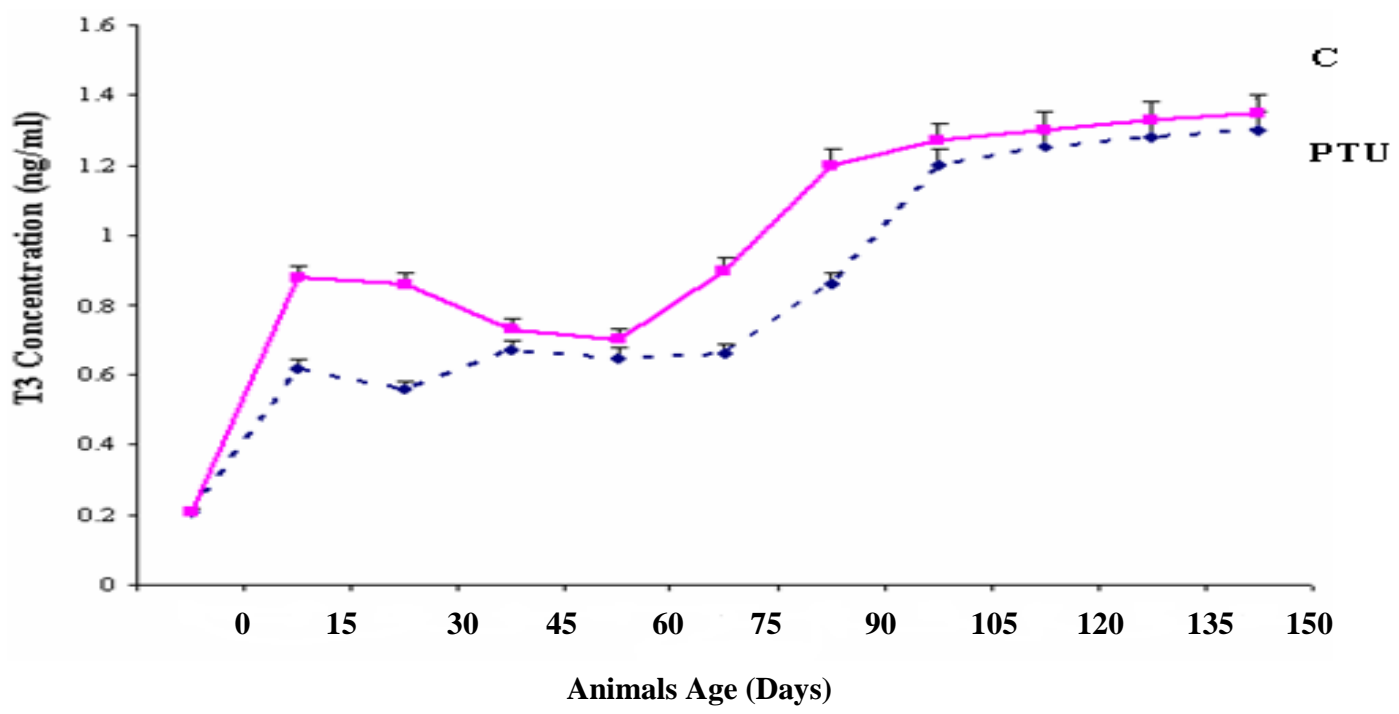

Fig. 3. Effect of PTU injection on blood plasma $T_{3}$ concentration $(\mathrm{ng} / \mathrm{ml})$ of male rabbits

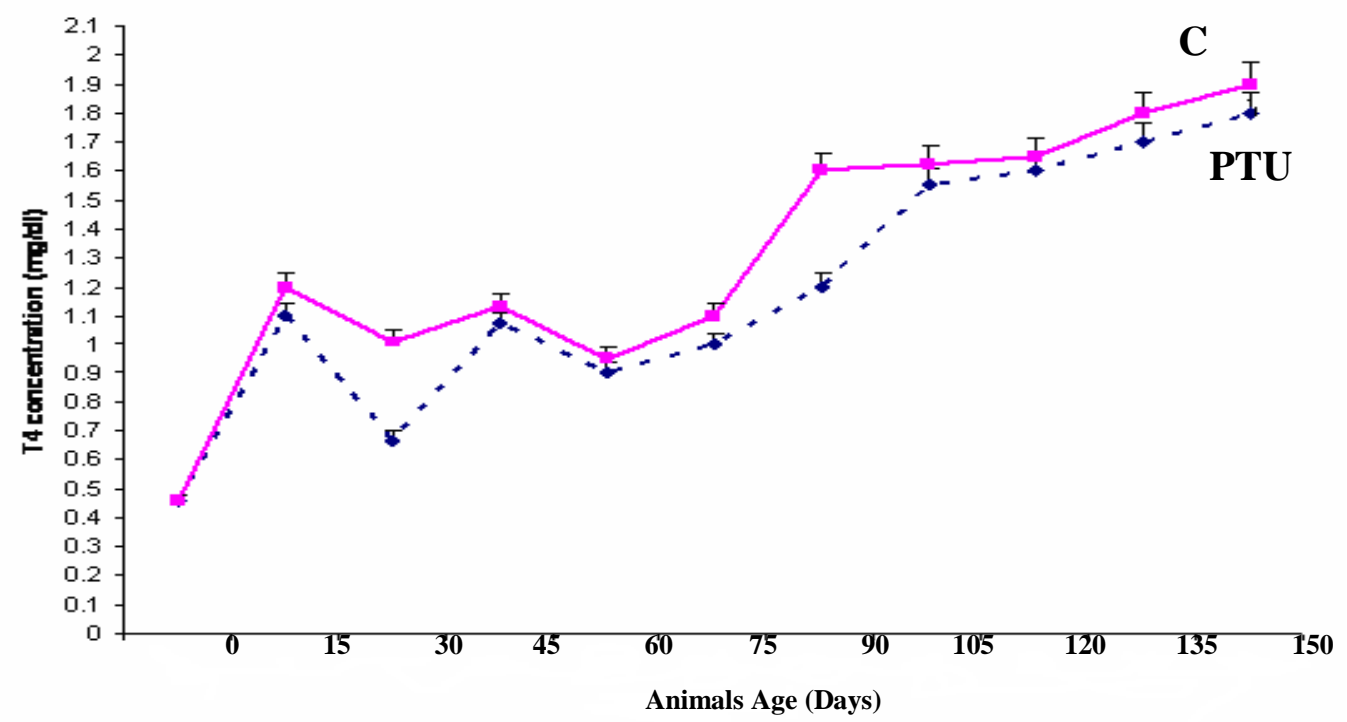

Fig. 4. Effect of PTU injection on blood plasma $\mathrm{T}_{4}$ concentration $(\mathrm{mg} / \mathrm{dl})$ of male rabbits 


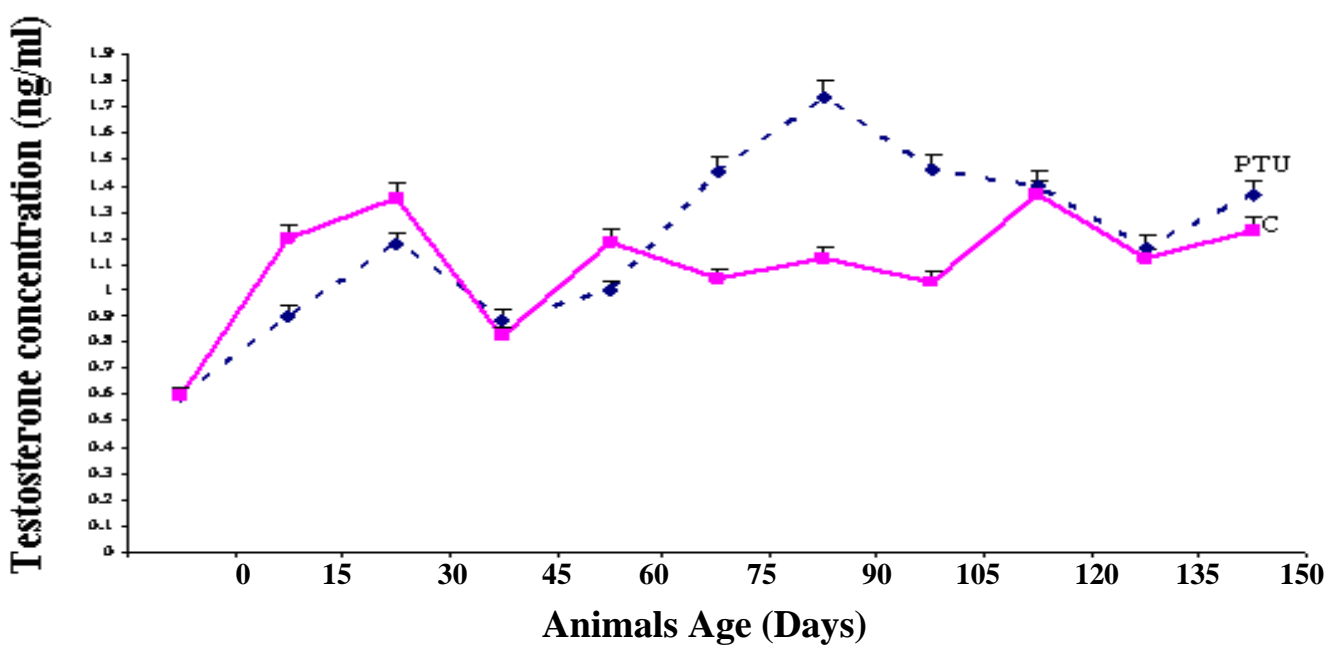

Fig. 5.Effect of PTU injection on blood plasma testosterone concentration $(\mathrm{ng} / \mathrm{ml})$ of male rabbits

\section{Histological Studies}

The percentage of seminiferous tubules and Leydig cells indices were increased $(\mathrm{P} \leq 0.001)$ in PTU treated group $(71,42 \%$ and $18.97 \%$ respectively, (table 2). The average values of long and short diameters of seminiferous tubules and Leydig cells were significantly greater in PTU treated rabbits compared with the control group (Table 2). Average seminiferous tubule epithelial thickness increased by $24.34 \%$ in PTU treated rabbits compared with the controls (Table 2). These findings are compatible with the results obtained by MendisH,agama and Sharma (1994), who reported a significant increase in the absolute volumes of seminiferous tubules, testis interstitium, Leydig cells, blood vessels, lymphatic space and connective tissue cells in the PTU treated rats. Hess et al., (1993) found that at 90 days of age mean seminiferous tubule diameter and length increased in the PTU treated rats, the seminiferous tubule length increased by $44 \%$ and tubular volume increased by $60 \%$; there were no significant differences in the percent area occupied by the seminiferous tubules in testicular cross-section of control and PTU treated animals. Van Haaster et al., (1992), Hess et al., (1993), Joyce et al., (1993), Hardy et al., (1993 and 1996) and Meisami et al., (1994) have shown that transient neonatal hypothyroidism induced by treatment with PTU, increased Sertoli cell and Leydig cell numbers in the adult rats and mice. The increase of seminiferous tubules index observed in the present study, in PTU treated rabbits may be due to the increased number of Sertoli and Leydig cells observed by others (Meisami et al., 1994 and Hardy et al., 1993 and 1996), and / or the layers of seminiferous tubules epithelium (Table 2). Finally, Yan Sun et al. (2015) demonstrated that thyroid hormones $(\mathrm{TH})$ inhibit the proliferation of piglet sertoli cells (SCs) via the suppression of phosphoinositide 3-kinase (PI3K/Akt) signaling pathway.

\section{Analysis of Semen Quality}

Compared with the control group the ejaculate volume, sperm concentration and advanced motility of semen in PTU treated rabbits (Table 3) were significantly higher $(\mathrm{P} \leq 0.0001)$ during the study period while percentage of dead and abnormal spermatozoa were significantly lower $(\mathrm{P} \leq 0.0001)$. The average sperm concentration $/ \mathrm{ml}$ and advanced motility were $485.57 \times 10^{6}$ versus $312.07 \times 10^{6}$ and $87.21 \%$ versus $78.23 \%$ for PTU and control groups, respectively. The percentages of abnormal and dead spermatozoa were $16.07 \%$ vs. $20.95 \%$ and $5.03 \%$ versus $12.33 \%$ for treated and control groups respectively (Table 3 ). These findings are compatible with the results of other studies (Cooke 1991, Cooke and Meisami 1991, Cooke et al., 1991 and 1993 and Kirby et al., 1997) who found that the daily sperm production (DSP) was increased at 160 days of age up to $140 \%$ in adult PTU treated rats. Kirby et al., (1996) found that treatment of commercial broilers fed with $0.1 \%$ dietary PTU at 6 to 12 week of age increased daily sperm production per gram of testis by $36 \%$ compared to control. In the current study, the increase of ejaculate volume, sperm concentration, sperm motility as well as the decrease of the percentage of dead and abnormal spermatozoa may be a result of increased seminiferous tubules index in PTU treated rabbits (Table 2) and / or the increased number of Sertoli and Leydig cells observed by others in rats (Meisami et al., 1994, Hardy et al., 1993 and 1996). The mechanism (s) by which thyroid hormones suppress proliferation and induce differentiation in Sertoli cells is still unknown. Recent studies indicate that $T_{3}$ might be able to control Sertoli cell proliferation by acting through specific cyclindependent kinase inhibitors (Holsberger et al., 2005), a family of proteins that directly interact with the cell cycle (Sherr and Roberts 1995), and /or by a mechanism involving connexin43 (Cx43), a constitutive protein of gap junctions (Gilleron et al., 2006). 
Table 1. Mean $\pm \mathrm{SE}$ of testis measurements and percentage of testis weight to body weight in control and PTU treated rabbits

\begin{tabular}{|c|c|c|c|c|c|}
\hline Age (days) & Treatments & L. (cm) & W. $(\mathrm{cm})$ & Wt. (gm) & $\% \mathrm{Wt}$. \\
\hline \multirow{3}{*}{$\mathbf{0}$} & PTU & $0.30 \pm 0.05$ & $0.12 \pm 0.02$ & $0.002 \pm 0.03$ & $0.0004 \pm 0.006$ \\
\hline & $\mathrm{C}$ & $0.30 \pm 0.05$ & $0.12 \pm 0.02$ & $0.002 \pm 0.03$ & $0.0004 \pm 0.006$ \\
\hline & Overall mean & 0.30 & 0.12 & 0.002 & 0.0004 \\
\hline \multirow{4}{*}{30} & PTU & $1.08 \pm 0.05$ & $0.35 \pm 0.02$ & $0.20 \pm 0.03$ & $0.046 \pm 0.003$ \\
\hline & $\mathrm{C}$ & $0.75 \pm 0.05$ & $0.29 \pm 0.02$ & $0.18 \pm 0.03$ & $0.031 \pm 0.003$ \\
\hline & Overall mean & 0.915 & 0.32 & 0.19 & 0.038 \\
\hline & PTU & $1.70 \pm 0.04$ & $0.65 \pm 0.02$ & $0.29 \pm 0.02$ & $0.028 \pm 0.003$ \\
\hline \multirow{2}{*}{60} & $\mathrm{C}$ & $1.45 \pm 0.04$ & $0.46 \pm 0.02$ & $0.22 \pm 0.02$ & $0.018 \pm 0.003$ \\
\hline & Overall mean & 1.57 & 0.56 & 0.26 & 0.023 \\
\hline \multirow{4}{*}{90} & PTU & $2.66 \pm 0.05$ & $0.96 \pm 0.02$ & $1.78 \pm 0.03$ & $0.115 \pm 0.003$ \\
\hline & $\mathrm{C}$ & $2.33 \pm 0.05$ & $0.92 \pm 0.02$ & $1.28 \pm 0.03$ & $0.057 \pm 0.003$ \\
\hline & Overall mean & 2.49 & 0.94 & 1.53 & 0.086 \\
\hline & PTU & $3.01 \pm 0.05$ & $1.25 \pm 0.02$ & $2.40 \pm 0.03$ & $0.105 \pm 0.003$ \\
\hline \multirow{2}{*}{120} & $\mathrm{C}$ & $2.63 \pm 0.05$ & $1.12 \pm 0.02$ & $2.08 \pm 0.03$ & $0.075 \pm 0.003$ \\
\hline & Overall mean & 2.82 & 1.18 & 2.24 & 0.09 \\
\hline \multirow{3}{*}{150} & PTU & $3.37 \pm 0.05$ & $1.35 \pm 0.02$ & $2.81 \pm 0.03$ & $0.101 \pm 0.003$ \\
\hline & $\mathrm{C}$ & $2.99 \pm 0.05$ & $1.14 \pm 0.02$ & $2.38 \pm 0.03$ & $0.077 \pm 0.003$ \\
\hline & Overall mean & 3.18 & 1.24 & 2.60 & 0.089 \\
\hline \multirow[b]{2}{*}{$\begin{array}{c}\text { Overall } \\
\text { Mean }\end{array}$} & PTU & 2.02 & 0.78 & 1.25 & 0.066 \\
\hline & $\mathrm{C}$ & 1.74 & 0.67 & 1.02 & 0.043 \\
\hline SE & & 0.009 & 0.002 & 0.0031 & 0.00003 \\
\hline Probability & & 0.0001 & 0.0001 & 0.0001 & 0.0001 \\
\hline
\end{tabular}

Within the same column any two means having the same subscript do not differ significantly (P $\leq 0.05)$ from each other. L: length of testis $(\mathrm{cm})$. W: width of testis $(\mathrm{cm})$. Wt: weight of testis $(\mathrm{gm})$. \% Wt: \% Weight of testis to body weight.

Table 2. Means \pm SE of seminiferous tubules (S.T.) measurements in control and PTU treated rabbits

\begin{tabular}{|c|c|c|c|c|c|}
\hline \multirow{2}{*}{ Traits } & \multirow{2}{*}{ Treatments } & \multicolumn{3}{|c|}{ Age (days) } & \multirow{2}{*}{$\begin{array}{c}\text { Overall } \\
\text { mean }\end{array}$} \\
\hline & & 60 & 120 & 150 & \\
\hline \multirow{4}{*}{$\begin{array}{l}\text { Long diameter } \\
\text { of S.T. }(\mu \mathrm{m})\end{array}$} & PTU & $84.85 \pm 1.24$ & $206.00 \pm 1.24$ & $246.50 \pm 1.24$ & \multirow{4}{*}{$\begin{array}{l}179.12 \\
135.14 \\
32.57^{*}\end{array}$} \\
\hline & $\mathrm{C}$ & $78.02 \pm 1.24$ & $157.40 \pm 1.24$ & $170.00 \pm 1.24$ & \\
\hline & Differences $(\%)$ & $8.75^{\mathrm{c}}$ & $30.88^{\mathrm{b}}$ & $45.00^{\mathrm{a}}$ & \\
\hline & Overall mean & $81.43^{\mathrm{c}}$ & $181.70^{\mathrm{b}}$ & $208.25^{\mathrm{a}}$ & \\
\hline \multirow{4}{*}{$\begin{array}{l}\text { Short diameter } \\
\text { of S.T. }(\mu \mathrm{m})\end{array}$} & PTU & $74.14 \pm 1.09$ & $192.95 \pm 1.09$ & $227.87 \pm 1.09$ & \multirow{4}{*}{$\begin{array}{l}164.98 \\
129.63 \\
27.27^{*}\end{array}$} \\
\hline & $\mathrm{C}$ & $67.87 \pm 1.09$ & $158.30 \pm 1.09$ & $162.72 \pm 1.09$ & \\
\hline & Differences (\%) & $9.24^{\mathrm{c}}$ & $21.89^{\mathrm{b}}$ & $40.04^{\mathrm{a}}$ & \\
\hline & Overall mean & $71.00^{\mathrm{c}}$ & $175.62^{\mathrm{b}}$ & $195.30^{\mathrm{a}}$ & \\
\hline \multirow{4}{*}{$\begin{array}{c}\text { Epithelium } \\
\text { thickness of } \\
\text { S.T. }(\mu \mathrm{m})\end{array}$} & PTU & $22.30 \pm 0.79$ & $71.30 \pm 0.79$ & $80.68 \pm 0.79$ & \multirow{4}{*}{$\begin{array}{l}58.09 \\
46.72 \\
24.34^{*}\end{array}$} \\
\hline & C & $21.73 \pm 0.79$ & $55.06 \pm 0.79$ & $63.37 \pm 0.79$ & \\
\hline & Differences (\%) & & $29.5^{\mathrm{a}}$ & $27.32^{\mathrm{a}}$ & \\
\hline & Overall mean & & $63.18^{\mathrm{b}}$ & $72.02^{\mathrm{a}}$ & \\
\hline \multirow{4}{*}{$\begin{array}{c}\text { No. of } \\
\text { epithelial layers } \\
\text { of S.T. }\end{array}$} & PTU & $2.04 \pm 0.08$ & $5.87 \pm 0.08$ & $6.65 \pm 0.08$ & \multirow{4}{*}{$\begin{array}{l}4.85 \\
4.53 \\
7.06^{*}\end{array}$} \\
\hline & $\mathrm{C}$ & $1.86 \pm 0.08$ & $5.61 \pm 0.08$ & $6.14 \pm 0.08$ & \\
\hline & Differences (\%) & $9.68^{\mathrm{a}}$ & $4.63^{\mathrm{b}}$ & $8.31^{\mathrm{a}}$ & \\
\hline & Overall mean & $1.95^{\mathrm{c}}$ & $5.74^{\mathrm{b}}$ & $6.39^{\mathrm{a}}$ & \\
\hline \multirow{4}{*}{$\begin{array}{l}\text { S.T size }(\mu \mathrm{m}) \\
\quad \text { (index) }\end{array}$} & PTU & $6290.77 \pm 373.33$ & $39747.70 \pm 373.33$ & $56169.95 \pm 373.33$ & \multirow{4}{*}{$\begin{array}{c}33069.47 \\
19291.35 \\
71.42^{*}\end{array}$} \\
\hline & $\mathrm{C}$ & $5295.22 \pm 373.33$ & $24916.42 \pm 373.33$ & $27662.40 \pm 373.33$ & \\
\hline & Differences (\%) & $18.80^{\mathrm{c}}$ & $59.52^{\mathrm{b}}$ & $103.06^{\mathrm{a}}$ & \\
\hline & Overall mean & $5792.99^{c}$ & $32332.06^{\mathrm{b}}$ & $41916.17^{\mathrm{a}}$ & \\
\hline \multirow{4}{*}{$\begin{array}{c}\text { Long diameter } \\
\text { of Leydig cells } \\
(\mu \mathrm{m})\end{array}$} & PTU & $7.21 \pm 0.11$ & $8.04 \pm 0.13$ & $9.14 \pm 0.11$ & \multirow{4}{*}{$\begin{array}{l}8.13 \\
7.57 \\
7.4^{*}\end{array}$} \\
\hline & $\mathrm{C}$ & $6.91 \pm 0.11$ & $7.80 \pm 0.13$ & $8.00 \pm 0.11$ & \\
\hline & Differences $(\%)$ & $4.34^{\mathrm{b}}$ & $3.08^{\mathrm{b}}$ & $14.25^{\mathrm{a}}$ & \\
\hline & Overall mean & $7.06^{\mathrm{c}}$ & $7.92^{\mathrm{b}}$ & $8.57^{\mathrm{a}}$ & \\
\hline \multirow{4}{*}{$\begin{array}{l}\text { Short diameter } \\
\text { of Leydig cells } \\
(\mu \mathrm{m})\end{array}$} & PTU & $6.23 \pm 0.09$ & $7.29 \pm 0.16$ & $8.00 \pm 0.11$ & \multirow{4}{*}{$\begin{array}{c}7.17 \\
6.50 \\
10.31^{*}\end{array}$} \\
\hline & $\mathrm{C}$ & $5.78 \pm 0.09$ & $6.51 \pm 0.11$ & $7.22 \pm 0.09$ & \\
\hline & Differences (\%) & $7.79^{\mathrm{b}}$ & $11.98^{\mathrm{a}}$ & $10.80^{\mathrm{a}}$ & \\
\hline & Overall mean & $6.00^{\mathrm{c}}$ & $6.90^{\mathrm{b}}$ & $7.61^{\mathrm{a}}$ & \\
\hline \multirow{4}{*}{$\begin{array}{c}\text { Leydig cell } \\
\text { nuclear index } \\
(\mu \mathrm{m})\end{array}$} & PTU & $44.92 \pm 1.37$ & $58.61 \pm 1.68$ & $73.12 \pm 2.37$ & \multirow{4}{*}{$\begin{array}{l}58.88 \\
49.49 \\
18.97^{*}\end{array}$} \\
\hline & $\mathrm{C}$ & $39.94 \pm 1.37$ & $50.77 \pm 1.37$ & $57.76 \pm 1.68$ & \\
\hline & Differences (\%) & $12.47^{\mathrm{c}}$ & $15.44^{\mathrm{b}}$ & $26.73^{\mathrm{a}}$ & \\
\hline & Overall mean & $42.43^{\mathrm{c}}$ & $54.69^{\mathrm{b}}$ & $65.44^{\mathrm{a}}$ & \\
\hline
\end{tabular}

In the same row any two means have the same subscript do not differ significantly $(\mathrm{P} \leq 0.05)$ from each other. 
Table 3. Means \pm SE of parameters of semen quality in control and PTU treated bucks

\begin{tabular}{|c|c|c|c|c|c|c|c|}
\hline \multirow{2}{*}{ Parameters } & \multirow{2}{*}{ Treatments } & \multicolumn{4}{|c|}{ Collecting months } & \multirow{2}{*}{$\begin{array}{c}\text { Overall } \\
\text { mean }\end{array}$} & \multirow{2}{*}{ Probability } \\
\hline & & 2 & 4 & 6 & 8 & & \\
\hline $\begin{array}{l}\text { Volume } \\
\text { (ml) }\end{array}$ & $\begin{array}{c}\text { PTU } \\
\text { C } \\
\text { Differences } \\
(\%) \\
\text { Overall } \\
\text { mean }\end{array}$ & $\begin{array}{c}0.82 \pm 0.07 \\
0.55 \pm 0.08 \\
\leqslant 9 \cdot 9^{c} \\
0.68\end{array}$ & $\begin{array}{c}1.00 \pm 0.08 \\
0.56 \pm 0.10 \\
78.57^{\mathrm{b}} \\
0.78\end{array}$ & $\begin{array}{c}1.08 \pm 0.07 \\
0.41 \pm 0.10 \\
163.42^{\mathrm{a}} \\
0.75\end{array}$ & $\begin{array}{c}0.76 \pm 0.08 \\
0.60 \pm 0.10 \\
26.67^{\mathrm{d}} \\
0.68\end{array}$ & $\begin{array}{c}0.91 \\
0.53 \\
71.70^{*}\end{array}$ & 0.0001 \\
\hline $\begin{array}{c}\text { Concentratio } \\
\mathbf{n} \\
\left(\mathbf{X} \mathbf{1 0}^{\mathbf{6}}\right)\end{array}$ & $\begin{array}{c}\text { PTU } \\
\text { C } \\
\text { Differences } \\
(\%) \\
\text { Overall } \\
\text { mean } \\
\text { PTU }\end{array}$ & $\begin{array}{c}330 \pm 20 \\
238 \pm 24 \\
38.66^{c} \\
284\end{array}$ & $\begin{array}{c}494.85 \pm 2 \\
3 \\
218.5 \pm 26 \\
126.48^{\mathrm{a}} \\
356.68\end{array}$ & $\begin{array}{c}523.35 \pm 22 \\
384.38 \pm 28 \\
36.15^{\mathrm{c}} \\
453.86\end{array}$ & $\begin{array}{c}594.1 \pm 25 \\
407.4 \pm 28 \\
45.83^{\mathrm{b}} \\
500.75\end{array}$ & $\begin{array}{l}485.57 \\
312.07 \\
55.60^{*}\end{array}$ & 0.0001 \\
\hline $\begin{array}{l}\text { Advanced } \\
\text { Motility }\end{array}$ & $\begin{array}{c}\mathrm{C} \\
\text { Differences } \\
(\%) \\
\text { Overall } \\
\text { mean }\end{array}$ & $\begin{array}{c}79.2 \pm 2 \\
71.41 \pm 2.7 \\
10.91^{\mathrm{b}} \\
75.31\end{array}$ & $\begin{array}{c}85.09 \pm 2.5 \\
78.49 \pm 2.9 \\
8.40^{\mathrm{b}} \\
81.79\end{array}$ & $\begin{array}{c}91.42 \pm 2.5 \\
80.11 \pm 3 \\
14.12^{\mathrm{ab}} \\
85.76\end{array}$ & $\begin{array}{c}93.16 \pm 2.8 \\
85.94 \pm 3 \\
8.40^{\mathrm{b}} \\
89.55\end{array}$ & $\begin{array}{l}87.21 \\
78.23 \\
11.48^{*}\end{array}$ & 0.0001 \\
\hline $\begin{array}{c}\% \text { Dead } \\
\text { Spermatozoa }\end{array}$ & $\begin{array}{c}\text { PTU } \\
\text { C } \\
\text { Differences } \\
(\%) \\
\text { Overall } \\
\text { PTU }\end{array}$ & $\begin{array}{c}9.91 \pm 1.3 \\
17.89 \pm 1.5 \\
-44.61^{\mathrm{c}} \\
13.9\end{array}$ & $\begin{array}{c}4.34 \pm 1.5 \\
11.44 \pm 1.7 \\
-62.06^{\mathrm{b}} \\
7.89\end{array}$ & $\begin{array}{c}4.45 \pm 1.4 \\
10.96 \pm 1.8 \\
-59.40^{\mathrm{b}} \\
7.71\end{array}$ & $\begin{array}{c}1.43 \pm 1.6 \\
9.04 \pm 1.8 \\
-84.18^{\mathrm{a}} \\
5.24\end{array}$ & $\begin{array}{c}5.03 \\
12.33 \\
-59.21^{*}\end{array}$ & 0.0001 \\
\hline $\begin{array}{c}\% \\
\text { Abnormality }\end{array}$ & $\begin{array}{c}\mathrm{C} \\
\text { Differences } \\
(\%) \\
\text { Overall } \\
\text { mean }\end{array}$ & $\begin{array}{c}17.82 \pm 0.7 \\
19.77 \pm 0.8 \\
-9.86^{\mathrm{d}} \\
18.79\end{array}$ & $\begin{array}{c}14.8 \pm 0.8 \\
20.61 \pm 0.8 \\
-28.19^{\mathrm{b}} \\
17.71\end{array}$ & $\begin{array}{c}14.6 \pm 0.7 \\
22.67 \pm 0.8 \\
-35.60^{\mathrm{a}} \\
18.63\end{array}$ & $\begin{array}{c}17.07 \pm 0.8 \\
20.77 \pm 0.8 \\
-17.81^{\mathrm{c}} \\
18.92\end{array}$ & $\begin{array}{c}16.07 \\
20.95 \\
-23.29\end{array}$ & 0.0001 \\
\hline $\begin{array}{l}\text { Seminal } \\
\text { Fructose }\end{array}$ & $\begin{array}{c}\text { PTU } \\
\text { C } \\
\text { Differences } \\
(\%) \\
\text { Overall } \\
\text { mean } \\
\end{array}$ & $\begin{array}{c}221 \pm 14.5 \\
195 \pm 17 \\
13.33^{\mathrm{a}} \\
208.11\end{array}$ & $\begin{array}{c}164.72 \pm 1 \\
6 \\
178.15 \pm 2 \\
0 \\
-7.54^{\mathrm{b}} \\
171.44 \\
\end{array}$ & $\begin{array}{c}139.59 \pm 15 \\
192.82 \pm 20 \\
-27.61^{\mathrm{d}} \\
166.21\end{array}$ & $\begin{array}{c}166.5 \pm 17 . \\
8 \\
202.87 \pm 2 \\
0 \\
-17.93^{\mathrm{c}} \\
184.68 \\
\end{array}$ & $\begin{array}{c}172.95 \\
192.21 \\
10.02\end{array}$ & 0.17 \\
\hline
\end{tabular}

In the same row any two means having the same subscript do not differ significantly $(\mathrm{P} \leq 0.05)$ from each other.

Moreover initial fructose was decreased by $10.02 \%$, on average. The seminal fructose decrease was insignificant $(\mathrm{P} \leq 0.17)$ in PTU treated rabbit bucks as compared with control bucks.

In conclusion, newborn male NZW rabbits treated with 6-n-propyl-2-thiouracil (PTU) resulted in increased testis size, ejaculate volume and sperm quality. More studies are needed to confirm the uses of PTU to produce male farm animals with big testis and high quality semen for artificial insemination centers.

\section{REFERENCES}

Ariyaratane, S. H. B., N. J. Mills, I. Mason, H. Mendis and S. M. L. C. agama, 2000. Effects of thyroid hormone on Leydig cell regeneration in the adult rat following ethane dimethane sulphonate treatment. Biology of Reproduction, $63,1115-1123$
Campbell, R. C., 1956. Nigrosin-Eosin as a stain for differentiating live and dead spermatozoa. Journal Agriculture Science, Cambridge, 48, 1-8.

Cooke, P. S., 1991. Thyroid hormones and testis development: A model system for increasing testis growth and sperm production. Annals of the New York Academy of Science, 637, 122-132.

Cooke, P. S. and E. Meisami, 1991. Early hypothyroidism in rats causes increased adult testis and reproductive organ size but does not change testosterone levels. Endocrinology, 129, 237-243.

Cook, P. S., J. D. Kirby and J. Porcelli, 1993. Increased testis growth and sperm production in adult rats following transient neonatal goitrogen treatment: Optimization of the propylthiouracil does effects of methimazole. Journal of Reproduction and Fertility, 97, 493-499.

Cooke, P. S., J. Porcelli and R. A. Hess, 1992. Induction of increased testis growth and sperm 
production in adult rats by neonatal administration of the goitrogen propylthiouracil (PTU).: The critical period. Biology of Reproduction, 46, 146-154.

Cooke, P. S., R. A. Hess, J. Porcelli and E. Meisami, 1991. Increased sperm production in adult rats following transient neonatal hypothyroidism. Endocrinology, 129, 244-248.

Dott, H. M. and G. D. Foster, 1972. A technique for studying the morphology of mammalian spermatozoa which are eosinophilic in a differential "live/dead" stain. Journal of Reprododuction and Fertility, 29, 443-445.

Duncan, D. B., 1955. Multiple range and multiple F test. Biometrics. 11, 1-42.

Gilleron, J., M. Nebout, L. Scarabelli, F. SenegasBalas, S. Palmero, D. Segretain and G. Pointis, 2006. A potential novel mechanism involving connexin 43 gap junction for control of sertoli cell proliferation by thyroid hormones. Journal of Cellular Physiology, 209, 153-161. Hardy M. P., Kirby J. D., Hess R. A., Cooke P. S. 1993. Leydig cells increase their number but decline in steroidogenic function in the adult rat after neonatal hypothyroidism. Endocrinology, 132, 2417-2420.

Hardy, M. P., R. S. Sharma, N. Arambepola K., C. M. Sottas, L. D. Russell, D. Bunick, R. A. Hess and P. S. Cooke, 1996. Increased proliferation of Leydig cells induced by neonatal hypothyroidism in the rat. Journal of Andrology, 17, 231-238.

Heidbrink, G., H. L. Esons and G. E. Seidel, 1980. Artificial insemination in commercial rabbit production. Colorado state univeristy. Experimental station Fort Collins. Bulletin, 5735, 1.

Hess, R. A., P. S. Cooke, D. Bunick and J. D. Kirby, 1993. Adult testicular enlargement induced by neonatal hypothyroidism is accompanied by increased Sertoli and germ cell numbers. Endocrinology, 132, 2607-2613.

Holsberger, D. R., G. M. Buchold, M.C. Leal, S. E. Kieswetter, D.A. O'Brien, R. A. Hess, L. R. Franca, H. Kiyokawa and P. S. Cooke, 2005. Cell-cycle inhibitors p27 Kipl and p21 Cip1 regulate murine Sertoli cell proliferation. Biology of Reproduction, 72, 1429-1436.

Joyce, K. L., J. Porcelli and P. S. Cooke, 1993. Neonatal goitrogen treatment increases adult testis size and sperm production in the mouse. Journal of Andrology, 14, 448- 455.

Kirby, J. D., M. V. Mankar, D. Hardesty and D. L. Kreider, 1996. Effect of transient prepubertal 6N-propyl-2-thiouracil treatment on testis development and function in the domestic fowl. Biology of Reproduction, 55, 910-916.

Kirby, J. D., P. S. Cooke, D. Bunick, R. A. Hess, Y. K. Kirby and F. W. Turek,1995. Does TSH potentiate the effects of neonatal PTU treatment on testis growth in the rat? Assist Reproduction Technology and Andrology, 7, 171-187.
Kirby, J. D., A. E. Jetton, P. S. Cooke, R. A. Hess, D. A. Bunick, J. F. Ackl, F. W. Turek and N. B. Schwartz, 1992. Developmental hormonal profiles accompanying the neonatal hypothyroidism-induced increase in adult testicular size and sperm production in the rat. Endocrinology, 131, 559-565.

Kirby, J. D., N. Arambepola, T. Porkka-Heiskanen, Y. K. Kirby, M. L. Rhoads, H. Nitta, A. E. Jetton, G. Iwamoto, J. G. L.Ackson, F. W. Turek and P. S. Cooke, 1997. Neonatal hypothyroidism permanently alters Follicle-Stimulating hormone and Luteinizing hormone production in the male rat. Endocrinology, 138, 2713-2721.

Knowlton, J. A., T. D. Siopes, M. L. Rhoads and J. D. Kirby, 1999. Effect of transient treatment with 6-N-propyl-thiouracil on testis development and function in breeder turkeys. Poultry Science, 78, 999-1005.

Mann, T., 1964. The biochemistry of semen and the male reproductive tract. London, Methuen co. Ltd. New York. John Viley, Sons. Inc.

Mann, T., 1948. Fructose content and fructolysis in semen. Practical application in the evaluation of semen quality. Journal of Agriculture Science, 38, 323-231.

Meisami, E., A. Najafi and P. S. Timiras, 1994. Enhancement of seminiferous tubular growth and spermatogenesis in testes of rats recovering from early hypothyroidism, A quantitative study. Cell Tissue Research, 275, 203-211.

Mendis-H,agama, S. M. L. C. and O. P. Sharma, 1994. Effects of neonatal administration of the reversible goitrogen propylthiouracil on the testis interstitium in adult rats. Journal of Reproduction and Fertility, 100, 85-92.

Nancy St-Pierre, J. Dufresne, A. A. Rooney and G. C. Daniel, 2003. Neonatal hypothyroidism alters the localization of gap junctional protein connexin 43 in the testis and messenger RNA levels in the epididymis of the rat. Biology of Reproduction, $68,1232-1240$.

Sanford, S.M, D.B. Beaton, B. E. How and W. M. Palmer, 1978. Photoperiod induced changes in $\mathrm{LH}, \mathrm{FSH}$, prolactin and testosterone secretion in the ram. Canadian Journal of Animal Science, 58, 123-128.

SAS., 2000. User's Guide Statistics. . Ed., SAS, Institute.Inc., Cary, N. C., USA.

Sherr, C.J. and J.M. Roberts, 1995. Inhibitors of mammalian G1 cyclin-dependent kinases. Genes and Development, 9, 1149-1163.

Simorangkir, D. R., D. M. de Kretser and N. G. Wreford, 1995. Increased numbers of Sertoli and germ cells in adult rat testes induced by synergistic action of transient neonatal hypothyroidism and neonatal hemicastration. Journal of Reproduction and Fertility, 104, 207213.

Subudhi, U., K. Das, B. Paital, S. Bhanja and G. B. N. Chainy, 2009. Supplementation of curcumin and vitamin $\mathrm{E}$ enhances oxidative stress, but 
restores hepatic histoarchitecture in hypothyroid rats. Life Sciences, 84, 372-379.

Tamasy, V., E. Meisami, A. Vallerga and P. S.Timiras, 1986. Rehabilitation from neonatal hypothyroidism, spontaneous motor activity, exploratory behavior, avoidance learning and response of pituitary-thyroid axis to stress in male rats. Psychoneuroendocrinology, 1, 91-103.

Van Haaster, L. H., F. H. De Jong, R. Docter and D. G. De Rooij, 1992. The effect of hypothyroidism on Sertoli cell proliferation, differentiation and hormone levels during testicular development in the rat. Endocrinology, 131, 1574- 1576.

Yan, S., Y. WeiRong, L. HongLin, W. Xian Zhong, C. Zhong Qiong, Z. JiaoJiao, W. Yi and L. XiaoMin , 2015. Thyroid hormone inhibits the proliferation of piglet Sertoli cell via PI3K signaling pathway. Theriogenology, 83, 86-94.

\footnotetext{
تأثير البروبايل ثيور اسيل على وظائف الخصي وصفات السائل المنوى لأرانب النيوزيلندى الابيض عصام ثروت- محمد صبره- عبد الهادى فاروق- هناء حسن منصور قسم الإنتاج الحيو انى، كلية الزر اعة، جامعة عين شمس، صندوق بريد 1 حدائق شبر اـ القاهرة- مصر.

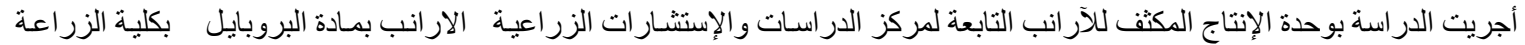

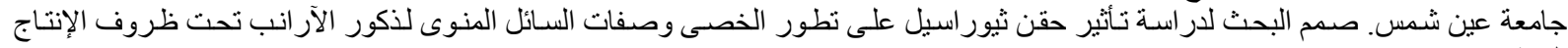
المكثف.

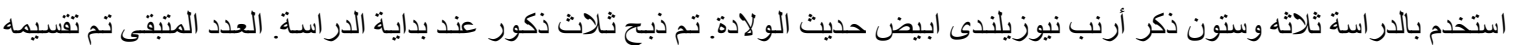

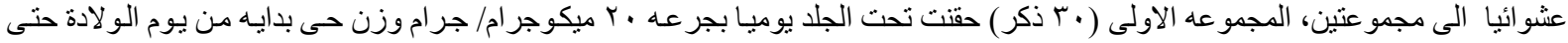

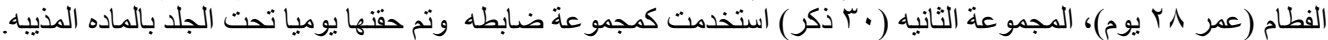

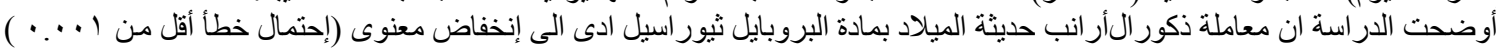

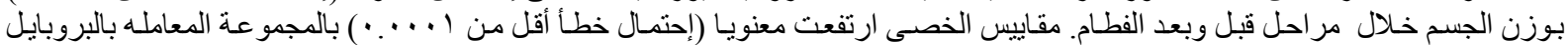

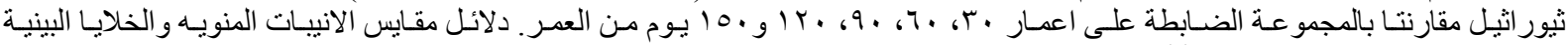

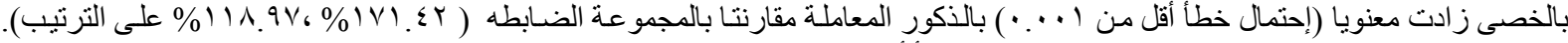

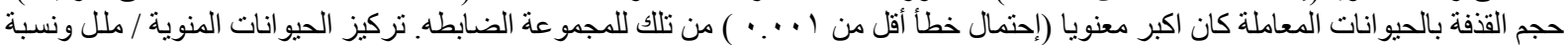

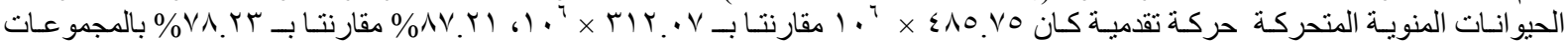

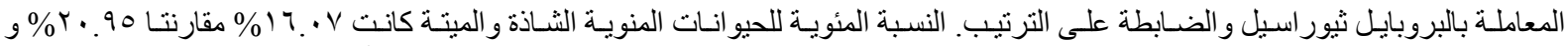

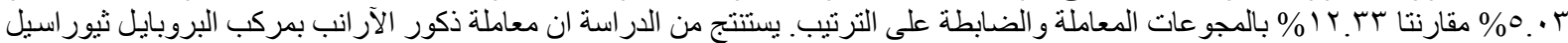

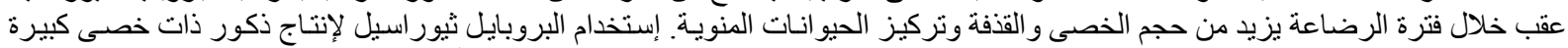

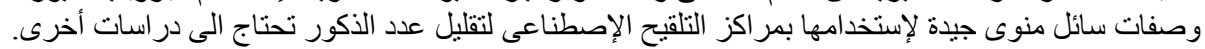

